\title{
Spatiotemporal Variations and Contributing Factors of Air Pollutants in Almaty, Kazakhstan
}

\author{
Aiymgul Kerimray ${ }^{1 *}$, Eldar Azbanbayev ${ }^{2}$, Bulat Kenessov $^{1}$, Pavel Plotitsyn ${ }^{3}$, \\ Danara Alimbayeva ${ }^{4}$, Ferhat Karaca ${ }^{5,6}$
}

${ }^{1}$ Center of Physical-Chemical Methods of Research and Analysis, Faculty of Chemistry and Chemical Technology, Al Farabi Kazakh National University, Almaty, Kazakhstan

${ }^{2}$ Department of Mechanical and Aerospace Engineering, School of Engineering and Digital Sciences, Nazarbayev University, Nur-Sultan, Kazakhstan

${ }^{3}$ Airkaz.org, Almaty, Kazakhstan

${ }^{4}$ National Hydrometeorological Service of Kazakhstan, Nur-Sultan, Kazakhstan

${ }^{5}$ Department of Civil and Environmental Engineering, Nazarbayev University, Nur-Sultan, Kazakhstan

${ }^{6}$ The Environment \& Resource Efficiency Cluster, Nazarbayev University, Nur-Sultan, Kazakhstan

\begin{abstract}
In this study, spatial and temporal patterns of $\mathrm{PM}_{10}, \mathrm{PM}_{2.5}, \mathrm{NO}_{2}, \mathrm{SO}_{2}$, and $\mathrm{CO}$ in Almaty, the largest city of Kazakhstan, in the period between 2013 and 2018 are explored. Severe degradation of air quality was observed from the data that were used in this study. Annual averages of $\mathrm{PM}_{2.5}, \mathrm{PM}_{10}$, and $\mathrm{NO}_{2}$ concentrations exceeded the WHO annual limits by 5.3, 3.9, and 3.2 times, respectively. The maximum levels were observed in the winter, while the minimum levels in the summer. Winter-to-summer difference was more noticeable for $\mathrm{PM}_{2.5}$ than for other pollutants. The winter pollution peaks demonstrate the high contribution of large- and small-scale coal combustion for heating, which could be exacerbated with lower winds and possible more frequent thermal inversions. There was a negative correlation between elevation and levels of $\mathrm{SO}_{2}, \mathrm{PM}_{2.5}$, and $\mathrm{PM}_{10}$, while no correlation was observed for $\mathrm{NO}_{2}$ and $\mathrm{CO}$, indicating that the former group could be mainly contributed by point sources located predominantly at lower elevations (e.g., power plants) and the latter group mainly originated from nonpoint sources distributed evenly across the city (e.g., transport). Urgent measures are needed to reduce emissions from the coal-fired power plant and from the domestic heating stoves.
\end{abstract}

Keywords: Aerosol; Air quality; Atmospheric air pollution; Particulate matter; Kazakhstan; Almaty.

\section{INTRODUCTION}

Rapid economic development, exploitation of natural resources, lax environmental regulations, and weak enforcement have led to environmental degradation in many locations in Kazakhstan (Russel et al., 2018). Almaty, the former capital and the largest urban center in Kazakhstan, is one of the most polluted cities in Kazakhstan (Russel et al., 2018; Kerimray et al., 2019), and one of the air pollution "hotspots" in the country, particularly with $\mathrm{NO}_{2}$ (Darynova et al., 2018). Almaty experienced a constant population and economic growth, which has inevitably resulted (and may continue to result in the future) in an increased number of transportation activities, urbanization, and increased energy

\footnotetext{
* Corresponding author.

Tel.: +77019089737

E-mail address: aiymgul.kerimray@cfhma.kz
}

demand (World Bank, 2017). Almaty was initially designed for less than a million dwellers (in 1990) (Nazhmetdinova et al., 2018); however, its population has reached 1.85 million due to massive migration waves (Committee of Statistics of the Ministry of the National Economy of the Republic of Kazakhstan, 2019a).

Currently, the city is heavily dependent on the use of coal: 2.6 million tons of coal in total were used in 2015 (World Bank, 2017). For the city of Almaty with its surrounding region, $64 \%$ of the electric energy supply originates from local power plants, and the remaining $36 \%$ are purchased from Pavlodar region (ALES, 2019). The coal-fired combined heat and power plant named "CHP-2", the largest power plant, located in the north-west of the city is equipped with an emulsifier for cleaning flue gases from ash and dust (ALES, 2019). The effectiveness of $\mathrm{SO}_{2}, \mathrm{NO}_{2}, \mathrm{PM}_{10}$, and $\mathrm{PM}_{2.5}$ removal at the CHP-2 are not reported. In Kazakhstan, emissions from coal-fired power plants are substantially higher than the limit values for power plants in Europe: 10 times for $\mathrm{PM}$, by $20 \%$ for $\mathrm{NO}_{\mathrm{x}}$ and 2.5 times for $\mathrm{SO}_{\mathrm{x}}$ 
(Concept on the Transition of the Republic of Kazakhstan to the "Green Economy", 2013).

Given that the maximum concentrations of $\mathrm{PM}_{10}, \mathrm{NO}_{2}$, and $\mathrm{SO}_{2}$ occur during wintertime, large- and small-scale heat production is a significant source of pollution (World Bank, 2013; Darynova et al., 2018). Residential and commercial buildings without access to district heating rely on coal or gas, which are often burned in inefficient stoves (Kerimray et al., 2018). Due to the cold climate and poor dispersion conditions, small-scale combustion can also contribute to episodic air pollution events in the wintertime (World Bank, 2013).

Elevated concentrations of $\mathrm{NO}_{2}$ and $\mathrm{CO}$ in Almaty can also indicate the contribution of the urban transport sector (World Bank, 2013). Most passenger cars (63\%) do not satisfy the requirements of the Euro 4 emission standard (UNDP, 2017), and 75\% of the cars are older than 7 years (Municipality of Almaty City, 2018). Quality of oil products is also an issue with frequent cases of noncompliance with fuel quality standards and the late introduction of fuel quality standards (Euro 3 and Euro 4) in 2018 (Kazenergy, 2017). The number of registered light-duty vehicles has increased by $6 \%$ annually over 2003-2018 reaching 471 thousand vehicles (Committee of Statistics of the Ministry of the National Economy of the Republic of Kazakhstan, 2019b), without accounting for unregistered vehicles entering and leaving the city on a daily basis from suburban areas.

Natural sources such as windblown dust are likely to have low contributions to the deterioration of the air quality in Almaty as dust and sand storms are more frequent in other locations, particularly in the southern desert zone of Kazakhstan (Issanova and Abuduwaili, 2017).

Exposure to ambient air pollution increases the mortality and morbidity as a result of increased risk of ischemic heart disease, cerebrovascular disease, lung cancer, chronic obstructive pulmonary disease and lower respiratory infections (Cohen et al., 2017). The epidemiological studies suggest that the prevalence of bronchial asthma and chronic obstructive pulmonary disease (COPD) in Almaty is high. The prevalence of "wheezing symptoms" was 74.4, 254.8, and 123.4 per 1000 people in Kyiv (Ukraine), Almaty (Kazakhstan), and Baku (Azerbaijan), respectively (Nugmanova et al., 2018a). Thus, in Almaty, it was 3.4 and 2.1 times higher than in Kyiv and Baku, respectively. The prevalence of chronic obstructive pulmonary disease (COPD) was 66.7 per 1000 people, which is 1.8-2.1 times higher compared to other cities of post-soviet countries (e.g., Ukraine and Azerbaijan) and the higher levels in Almaty were likely due to the poor environmental conditions (Nugmanova et al., 2018b). World Bank (2013) estimated that air pollution by $\mathrm{PM}_{10}$ and $\mathrm{PM}_{2.5}$ in Almaty resulted in an annual economic loss of 486 million US Dollars due to additional health care costs $(0.33 \%$ of the national Gross Domestic Product in 2011). These values have been estimated using exposure-response functions to the total suspended solids data from the National Air Quality Monitoring Network in 2011 for four regions of Kazakhstan (including Almaty).

There were few scientific studies on air quality in the cities of Kazakhstan, and Almaty is not an exception. Previous studies in Almaty focused on transportation-related emissions (Carlsen et al., 2013); benzene, toluene, ethylbenzene, and xylenes (BTEX) concentrations and ratios (Baimatova et al., 2016); CO, TSP and lead concentrations and compliance with sanitary standards (Nazhmetdinova et al., 2018); and aerosol variations and sources using Aqua-MODIS Collection 6.1 data (Rupakheti et al., 2019). World Health Organisation (WHO) Global Ambient Air Quality Database (WHO, 2018) does not contain data on $\mathrm{PM}_{10}$ and $\mathrm{PM}_{2.5}$ concentrations in Kazakhstan cities, and the recent report of United Nations Environment Program (UNEP) on air quality in Asia did also not include Kazakhstan (United Nations Environment Program, 2019). Thus, there is a clear gap in the knowledge of air quality levels in Kazakhstan in international databases and studies.

National Hydrometeorological Service of Kazakhstan "Kazhydromet" owns and operates the National Air Quality Monitoring Network (NAQMN) for many pollutants (total suspended particles - TSP, $\mathrm{NO}_{2}, \mathrm{SO}_{2}, \mathrm{CO}$, etc.) in the cities of Kazakhstan (and some villages). The number of measurement locations of $\mathrm{PM}_{2.5}$ and $\mathrm{PM}_{10}$ has gradually increased since 2016. In 2017, an independent $\mathrm{PM}_{2.5}$ measurement network (Airkaz) was established with a higher number of measurement stations than the NAQMN in the three largest cities of Kazakhstan. The real-time $\mathrm{PM}_{2.5}$ measurements are displayed at the Airkaz.org website.

Despite the deteriorating situation, there is a lack of studies exploring spatial-temporal variations of air pollutants and the impact of meteorology on air quality in the city. Studies on air quality are urgently needed because of the high public exposure to dangerous pollution levels, complex and unique topographic, and meteorological conditions. Similar studies have been conducted in other places where significant spatial and temporal variations of particulate matter and gaseous pollutants were detected using data from air quality measurements, and possible reasons for such variations were discussed (Alizadeh-Choobari et al., 2016).

In this work, spatial and temporal patterns of air quality in Almaty were studied based on the data from the NAQMN (TSP, $\mathrm{NO}_{2}, \mathrm{SO}_{2}, \mathrm{CO}$ ) and Airkaz $\left(\mathrm{PM}_{2.5}\right)$ during the years of 2013-2018. The effects of meteorological parameters on the pollutants were investigated. The spatiotemporal variation of air pollution and its relationships with distance to coalfired power plants and elevation above sea level have been discussed in detail by addressing possible sources of emissions. The proposed study will be the first comprehensive analysis of the urban air quality not only in Kazakhstan but also in Central Asia, where the degree and impacts of atmospheric pollution have yet to be adequately studied.

\section{METHODOLOGY}

\section{Study Area}

Almaty is located in the foothills of the northern slope of the Trans-Ili Alatau ridge of the Tien Shan mountain system (Fig. 1). The topographical and geographical conditions provide suitable conditions for the formation of inversion layers, restricting the vertical dispersion of pollutants, which may contribute to severe pollution in daily cycles. In general, 


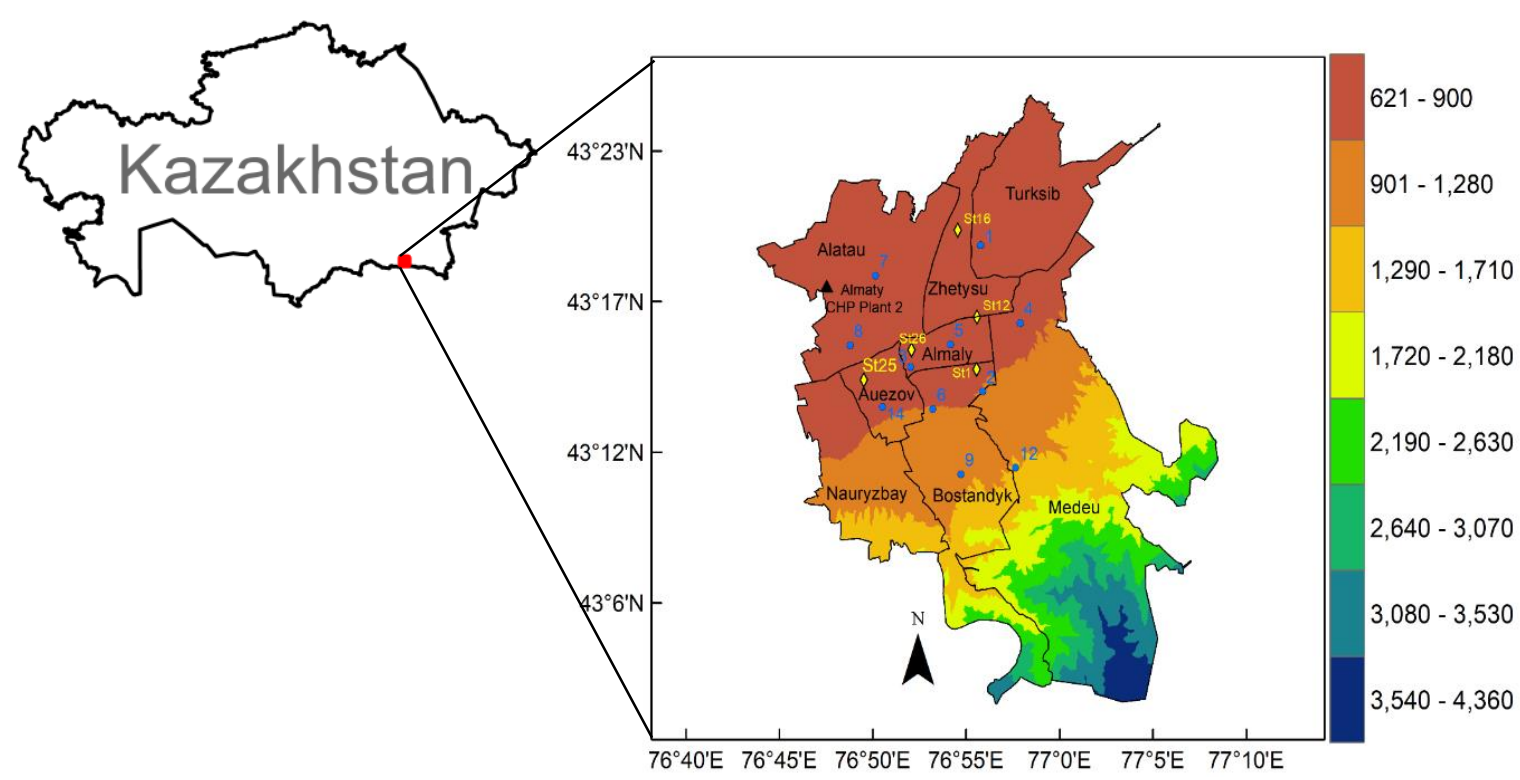

Fig. 1. Location of Almaty in Kazakhstan, and the map of Almaty with the elevation and location of air quality monitoring stations with station code (NAQMN stations marked with yellow; Airkaz stations marked with blue) and location of coalfired combined heat and power plant (black).

wind speed is very low or absent, influenced by the Siberian anticyclone in winter and the thermal depression on the territory of Kazakhstan in summer (Ecoservice, 2017). Poorly planned construction of the city and its infrastructure prevents horizontal dispersion of air pollutants (Ecoservice, 2017). The areas in the foothills surrounding the mountains were densely built-up in the mid-2000s, leading to a blocking effect on the clean air mass flows from the mountains (Ecoservice, 2017). Fig. 1 presents the location of Almaty in Kazakhstan and location monitoring network stations in Almaty.

\section{Data Obtained from the National Air Quality Monitoring Network (NAQNM)}

TSP, $\mathrm{NO}_{2}, \mathrm{SO}_{2}$, and $\mathrm{CO}$ data for 2013-2017 were obtained from Kazhydromet, which owns and operates the National Air Quality Monitoring Network (NAQMN). For TSP, $\mathrm{NO}_{2}$, $\mathrm{SO}_{2}$ and $\mathrm{CO}$ measurements, the gas sampler (aspirator) OP824TTs, gas analyzer K-100 and filters AFA-PV-20-1 for the aspirator OP-280 (all made in Russia) are employed. The data are published in information bulletins on a monthly and annual basis. Manual measurements of air quality are carried out three times a day at 07:00, 13:00 and 19:00 at these stations. Locations of five stations are provided in Fig. 1. Descriptive statistics of the pollutant concentrations over 2013-2017 are presented in Table 1.

The NAQMN data included total suspended particles (TSP) measurements while size-specific particulate matter (PM) measurements were not available (e.g., $\mathrm{PM}_{2.5}$ and $\mathrm{PM}_{10}$ ). The size of atmospheric PM can vary significantly in time and space. Ratios of $\mathrm{PM}_{10} / \mathrm{TSP}$ and $\mathrm{PM}_{2.5} / \mathrm{PM}_{10}$ have not been determined for Almaty and other cities of Kazakhstan, and there are no peer-reviewed publications on such ratios that can be applied for their conversion. In previous studies for Kazakhstan, World Bank (2013) used $\mathrm{PM}_{10} / \mathrm{TSP}=0.45$, and Kenessariyev et al. (2013) used the ratio of $\mathrm{PM}_{10} / \mathrm{TSP}=$
0.5 , so it was decided to use the ratio 0.45 in the current study. Future studies are needed with systematic measurements of TSP, $\mathrm{PM}_{10}, \mathrm{PM}_{2.5}$ to evaluate those ratios. $\mathrm{PM}_{10}$ values (estimated from TSP) from NAQMN may not be directly compared with the $\mathrm{PM}_{2.5}$ from Airkaz due to the significant spatiotemporal variations of PM in the study area.

\section{Data Obtained from the Airkaz}

Airkaz $\mathrm{PM}_{2.5}$ sensors (Pms5003 Plantower, China) were used to measure the concentrations of $\mathrm{PM}_{2.5}$ every minute. The concentrations were reported at the airkaz.org portal in real time with 24 stations: 16 sensors were put into operation consequently during 2017, and additional 8 sensors in 2018. Average daily $\mathrm{PM}_{2.5}$ values were determined from $22^{\text {nd }}$ March 2017 to $25^{\text {th }}$ March 2019 measurements, and the data for 2018 were used in the further analysis as it covers an entire year period. Descriptive statistics of the $\mathrm{PM}_{2.5}$ concentrations are presented in Table 2.

In addition to the above-mentioned monitoring networks, official measurements (NAQMN) of $\mathrm{PM}_{2.5}$ and $\mathrm{PM}_{10}$ concentration levels in Almaty started in 2016 at two full automatic stations located far from the city center: in the skirts of the mountains (Gornaya street 548) and airport area (Akhmetov street 50). Since 2017, three new stations were added to measure $\mathrm{PM}_{2.5}$ levels (also not in the city center): in the northern (Zorge street 14), the north-eastern (Zhankozha Batyr street 202), and the south-eastern ("Orbita" microdistrict) parts of the city. In this study, $\mathrm{PM}_{2.5}$ measurements by Airkaz were not compared with the NAQMN data since the provided NAQMN data do not include $\mathrm{PM}_{10}$ and $\mathrm{PM}_{2.5}$.

\section{Spatial Distribution of PM 2.5 Using Co-kriging}

The co-kriging method utilized in ArcGIS ${ }^{\circledR}$ Geostatistical Analyst tool (https://desktop.arcgis.com/ru/arcmap/) was used to map $\mathrm{PM}_{2.5}$ distribution that exceeds the WHO limit 
Table 1. Descriptive statistics of the pollutant concentrations (measured three times per day) over 2013-2017.

\begin{tabular}{|c|c|c|c|c|c|c|c|c|c|c|}
\hline \multirow[b]{2}{*}{ Station Code } & \multicolumn{5}{|c|}{$\mathrm{PM}_{10}\left(\mu \mathrm{g} \mathrm{m}^{-3}\right)$} & \multicolumn{5}{|c|}{$\mathrm{SO}_{2}\left(\mu \mathrm{g} \mathrm{m}^{-3}\right)$} \\
\hline & $\mathrm{S} 1$ & S12 & S16 & S25 & S26 & S1 & S12 & S16 & S25 & S26 \\
\hline $\mathrm{N}$ & 5648 & 4167 & 4167 & 4167 & 4167 & 5644 & 4167 & 4167 & 4167 & 4167 \\
\hline Mean & 43 & 131 & 96 & 41 & 58 & 12 & 13 & 15 & 12 & 13 \\
\hline Median & 45 & 90 & 90 & 45 & 45 & 11 & 11 & 12 & 10 & 11 \\
\hline STD & 29 & 87 & 69 & 28 & 38 & 9 & 10 & 14 & 11 & 10 \\
\hline Minimum & 0 & 0 & 0 & 0 & 0 & 0 & 0 & 0 & 0 & 0 \\
\hline Maximum & 360 & 540 & 540 & 450 & 450 & 110 & 86 & 110 & 178 & 89 \\
\hline \multicolumn{11}{|l|}{ Percentiles } \\
\hline 10 & 0 & 45 & 45 & 0 & 45 & 2 & 3 & 3 & 2 & 3 \\
\hline 25 & 45 & 45 & 45 & 45 & 45 & 6 & 6 & 6 & 5 & 6 \\
\hline 50 & 45 & 90 & 90 & 45 & 45 & 11 & 11 & 12 & 10 & 11 \\
\hline 75 & 45 & 180 & 135 & 45 & 90 & 16 & 17 & 19 & 17 & 17 \\
\hline 90 & 90 & 270 & 180 & 85 & 90 & 22 & 24 & 31 & 25 & 25 \\
\hline & \multicolumn{5}{|c|}{$\mathrm{CO}\left(\mathrm{mg} \mathrm{m}^{-3}\right)$} & \multicolumn{5}{|c|}{$\mathrm{NO}_{2}\left(\mu \mathrm{g} \mathrm{m}^{-3}\right)$} \\
\hline $\mathrm{N}$ & 1826 & 1826 & 1826 & 1826 & 1826 & 5644 & 4167 & 4167 & 4167 & 4167 \\
\hline Mean & 1.59 & 1.74 & 1.38 & 1.67 & 1.32 & 130 & 180 & 130 & 150 & 130 \\
\hline Median & 1.25 & 1.67 & 1.00 & 1.67 & 1.33 & 120 & 160 & 120 & 120 & 120 \\
\hline STD & 1.62 & 1.45 & 1.36 & 1.50 & 1.29 & 73 & 90 & 71 & 98 & 71 \\
\hline Minimum & 0.00 & 0.00 & 0.00 & 0.00 & 0.00 & 0 & 0 & 0 & 0 & 0 \\
\hline Maximum & 12.25 & 13.33 & 10.67 & 10.67 & 15.00 & 800 & 880 & 500 & 500 & 460 \\
\hline \multicolumn{11}{|l|}{ Percentiles } \\
\hline 10 & 0.00 & 0.00 & 0.00 & 0.00 & 0.00 & 80 & 50 & 50 & 60 & 50 \\
\hline 25 & 0.25 & 0.68 & 0.33 & 0.67 & 0.67 & 110 & 80 & 80 & 80 & 80 \\
\hline 50 & 1.25 & 1.67 & 1.00 & 1.67 & 1.33 & 160 & 120 & 120 & 120 & 120 \\
\hline 75 & 2.25 & 2.33 & 2.00 & 2.33 & 1.67 & 230 & 160 & 200 & 160 & 160 \\
\hline 90 & 3.50 & 3.33 & 3.00 & 3.33 & 2.67 & 310 & 220 & 290 & 230 & 220 \\
\hline
\end{tabular}

Table 2. Descriptive statistics of the average daily $\mathrm{PM}_{2.5}$ concentrations $\left(\mu \mathrm{g} \mathrm{m}^{-3}\right)$ observed in 2018.

\begin{tabular}{|c|c|c|c|c|c|c|c|c|c|c|c|}
\hline & S1 & $\mathrm{S} 2$ & S3 & S4 & S5 & S6 & S7 & S8 & S9 & S12 & S14 \\
\hline $\mathrm{N}$ & 301 & 320 & 355 & 282 & 350 & 351 & 269 & 279 & 305 & 358 & 352 \\
\hline Mean & 71 & 55 & 54 & 45 & 61 & 49 & 81 & 49 & 38 & 27 & 57 \\
\hline Median & 46 & 31 & 29 & 23 & 32 & 27 & 62 & 24 & 25 & 22 & 31 \\
\hline STD & 62 & 64 & 57 & 50 & 67 & 50 & 66 & 55 & 32 & 19 & 60 \\
\hline Minimum & 10 & 13 & 6 & 6 & 6 & 4 & 11 & 7 & 5 & 6 & 6 \\
\hline Maximum & 340 & 851 & 304 & 283 & 387 & 292 & 369 & 331 & 171 & 193 & 345 \\
\hline \multicolumn{12}{|l|}{ Percentiles } \\
\hline 10 & 23.5 & 17.9 & 11.5 & 10.9 & 13.3 & 11.0 & 22.5 & 13.1 & 11.0 & 11.4 & 11.8 \\
\hline 25 & 30.2 & 22.4 & 16.4 & 14.4 & 19.0 & 15.5 & 32.8 & 17.5 & 15.2 & 15.0 & 16.9 \\
\hline 50 & 45.6 & 31.2 & 28.6 & 22.6 & 31.5 & 27.1 & 62.1 & 24.4 & 25.1 & 21.5 & 30.8 \\
\hline 75 & 89.0 & 73.2 & 71.2 & 52.7 & 75.4 & 61.9 & 108.2 & 62.4 & 50.2 & 31.0 & 74.7 \\
\hline 90 & 152.4 & 122.6 & 127.2 & 128.3 & 143.0 & 117.2 & 158.4 & 113.4 & 85.3 & 49.1 & 140.0 \\
\hline
\end{tabular}

across Almaty in 2018. The digital elevation model (DEM) was used from the Shuttle Radar Topography Mission (SRTM) data (USGS, 2019) as a secondary dataset. In order to build the map, we selected ordinary co-kriging with logarithmic transformation of primary data with a constant order of trend removal with local polynomial interpolation as the data were not normally distributed. The semivariogram contains 12 lags with a size of 0.058 and no shift. The selected model type was stable, without anisotropy.

\section{Meteorological Parameters}

NAQMN data did not contain a full dataset on meteorology. Therefore, the meteorological parameters such as wind speed, wind direction, temperature, relative humidity, precipitation were obtained from http://rp5.kz website (Weather Schedule, 2020), which collects and archives the data from the international exchange data server of National Oceanic and Atmospheric Administration (USA) in SYNOP and METAR formats from the station located at $43.15^{\circ} \mathrm{N}$, $76.57^{\circ} \mathrm{E}$ and elevation of $848 \mathrm{~m}$ above sea level.

\section{RESULTS AND DISCUSSION}

\section{Analysis of NAQMN Data}

Long-term Variability of $\mathrm{PM}_{10}, \mathrm{NO}_{2}, \mathrm{SO}_{2}$, and $\mathrm{CO}$

At all NAQMN stations, the annual average concentrations 
of $\mathrm{NO}_{2}$ and $\mathrm{PM}_{10}$ exceeded $\mathrm{WHO}$ annual limit values. The annual average concentration of $\mathrm{PM}_{10}$ has increased from $52.7 \mu \mathrm{g} \mathrm{m}^{-3}$ to $86.7 \mu \mathrm{g} \mathrm{m}^{-3}$ over 2013-2016, followed by a decline to $78.5 \mu^{g^{-3}}$ in 2017 , exceeding the WHO annual limit value $\left(20 \mu \mathrm{g} \mathrm{m}^{-3}\right)$ by 3.9 times in 2017 (Fig. 2). This value is slightly higher than the world's average urban $\mathrm{PM}_{10}$ level of $71 \mu \mathrm{g} \mathrm{m}^{-3}$, which ranges by region from 21 to $142 \mu \mathrm{g} \mathrm{m}^{-3}$ (WHO, 2018). The annual average $\mathrm{NO}_{2}$ concentration had a fluctuating trend, exceeding the WHO annual limit value $\left(40 \mu \mathrm{g} \mathrm{m}^{-3}\right)$ by 3.2 times in 2017. Darynova et al. (2018) also reported a similar fluctuating trend of $\mathrm{NO}_{2}$ in 2013 2016 based on the observations of the NASA Aura Satellite. $\mathrm{NO}_{2}$ and $\mathrm{PM}_{10}$ concentration levels declined in 2017 compared to 2016, and there is not a piece of evidence that this downward trend would persist in the following years.

Of $\mathrm{PM}_{10}$ levels, the urban air quality in Almaty was considerably worse compared to the European countries. The WHO annual air quality limit for $\mathrm{PM}_{10}$ was exceeded at $51 \%$ stations (1492 out of 2 927) in Europe, and the European Union (EU) annual limit value $\left(40 \mu \mathrm{g} \mathrm{m}^{-3}\right)$ was also exceeded in $7 \%$ of all the reporting stations (European Environment Agency, 2019). As for Kazakhstan, the EU annual limit value $\left(40 \mu \mathrm{g} \mathrm{m}^{-3}\right)$ was not exceeded in one (out of five) station only in 2013 and 2014. The WHO annual air quality limit for $\mathrm{NO}_{2}$ was exceeded at $10 \%$ of all stations measuring $\mathrm{NO}_{2}$ in Europe (European Environment Agency), while in Kazakhstan it was exceeded at all five stations.

$\mathrm{CO}$ concentrations declined from $2.6 \mathrm{mg} \mathrm{m}^{-3}$ in 2013 to $1.5 \mathrm{mg} \mathrm{m}^{-3}$ (by $43 \%$ ) in 2017. The annual concentration of $\mathrm{SO}_{2}$ in 2017 remained at the level of $2013\left(12 \mu \mathrm{g} \mathrm{m}^{-3}\right)$. Rapidly declining CO concentration levels with simultaneously increasing trends of $\mathrm{PM}_{10}$ over 2013-2017 may indicate changes in the shares of contribution sources: declining share of transport emissions $\left(\mathrm{CO}, \mathrm{NO}_{2}\right)$ and increasing level of coal combustion $\left(\mathrm{PM}_{10}\right)$. Such declining/stable trends of $\mathrm{CO}$ and $\mathrm{NO}_{2}$ could be as a result of policies and measures in the transport system of the city such as an introduction of Euro 4 fuel quality standard, construction of the subway (only one route), optimization of transport flows with one- way streets, improvement of public transport by renewing the stock of buses, online payment system for bus and mobile application with bus routes. However, due to continuous urbanization and increased number of vehicles, these measures could be surpassed leading to increasing emissions trends in future.

\section{Monthly Variations of $\mathrm{PM}_{10}, \mathrm{NO}_{2}, \mathrm{SO}_{2}, \mathrm{CO}$ and Meteorological Parameters}

Monthly average concentrations of $\mathrm{PM}_{10}, \mathrm{NO}_{2}, \mathrm{SO}_{2}$, and $\mathrm{CO}$ show a distinct seasonal variability. Fig. 3 depicts the annual cycle of the $\mathrm{PM}_{10}, \mathrm{NO}_{2}, \mathrm{SO}_{2}$, and $\mathrm{CO}$ based on their monthly average concentrations. All of the measured pollutants reached their peak values in the winter months at all stations (with the exception of Station 12) and minimum values were during non-heating months. Half of the monthly maximum concentration values were observed in January. Winter peaks demonstrate the high contribution of fuel combustion for heat generation (from CHPs, heat-only plants, and smallscale household solid fuels burning) because traffic congestion is throughout the year. High pollution levels in the winter time could also be impacted by lower level of atmospheric boundary layer and wind speeds, preventing horizontal and vertical dispersion.

Station 12, which is located in the center of the city with a high traffic load, depict different monthly trends compared to other stations (with peaks for $\mathrm{PM}_{10}$ and $\mathrm{NO}_{2}$ in July and September). This may be explained by the traffic emissions that contribute to air pollution at this location. The highest ratio of maximum to minimum monthly concentration (across all stations) was observed for $\mathrm{PM}_{10}$ (5.7), followed by $\mathrm{CO}$ (3.4), $\mathrm{NO}_{2}$ (2.4) and $\mathrm{SO}_{2}$ (2.4). This is because $\mathrm{PM}_{10}$ variation across stations was higher compared to other pollutants. Within one station, the ratio of maximum to minimum monthly concentration was ranging $1.5-1.9$ for $\mathrm{PM}_{10}, 1.2-2.4$ for $\mathrm{SO}_{2}, 1.9-2.6$ for $\mathrm{CO}$ and 1.4-2 for $\mathrm{NO}_{2}$.

January, which is characterized by high levels of pollution, is a month with the lowest wind speed. The lowest wind speed values were observed in the cold season with the
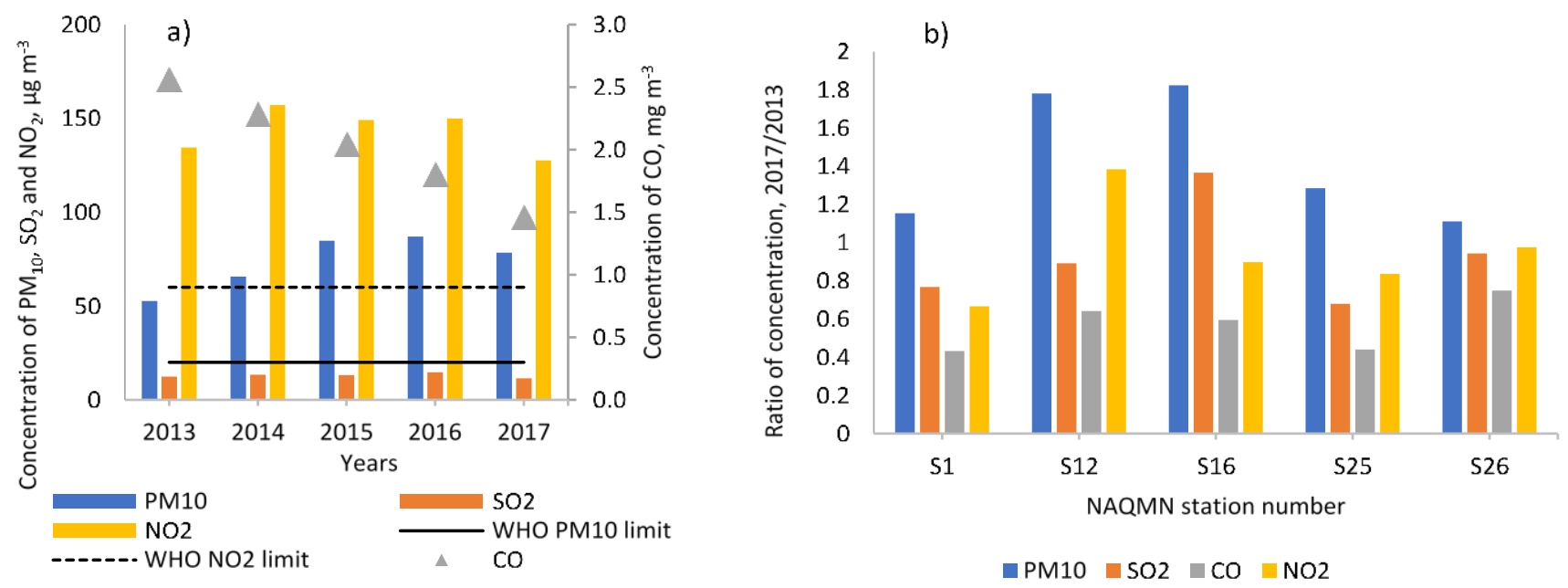

Fig. 2. Annual average concentrations of (a) $\mathrm{PM}_{10}, \mathrm{NO}_{2}, \mathrm{SO}_{2}$ and $\mathrm{CO}$ in 2013-2017 years in Almaty and (b) ratios of 2017/2013 concentration levels by stations. 

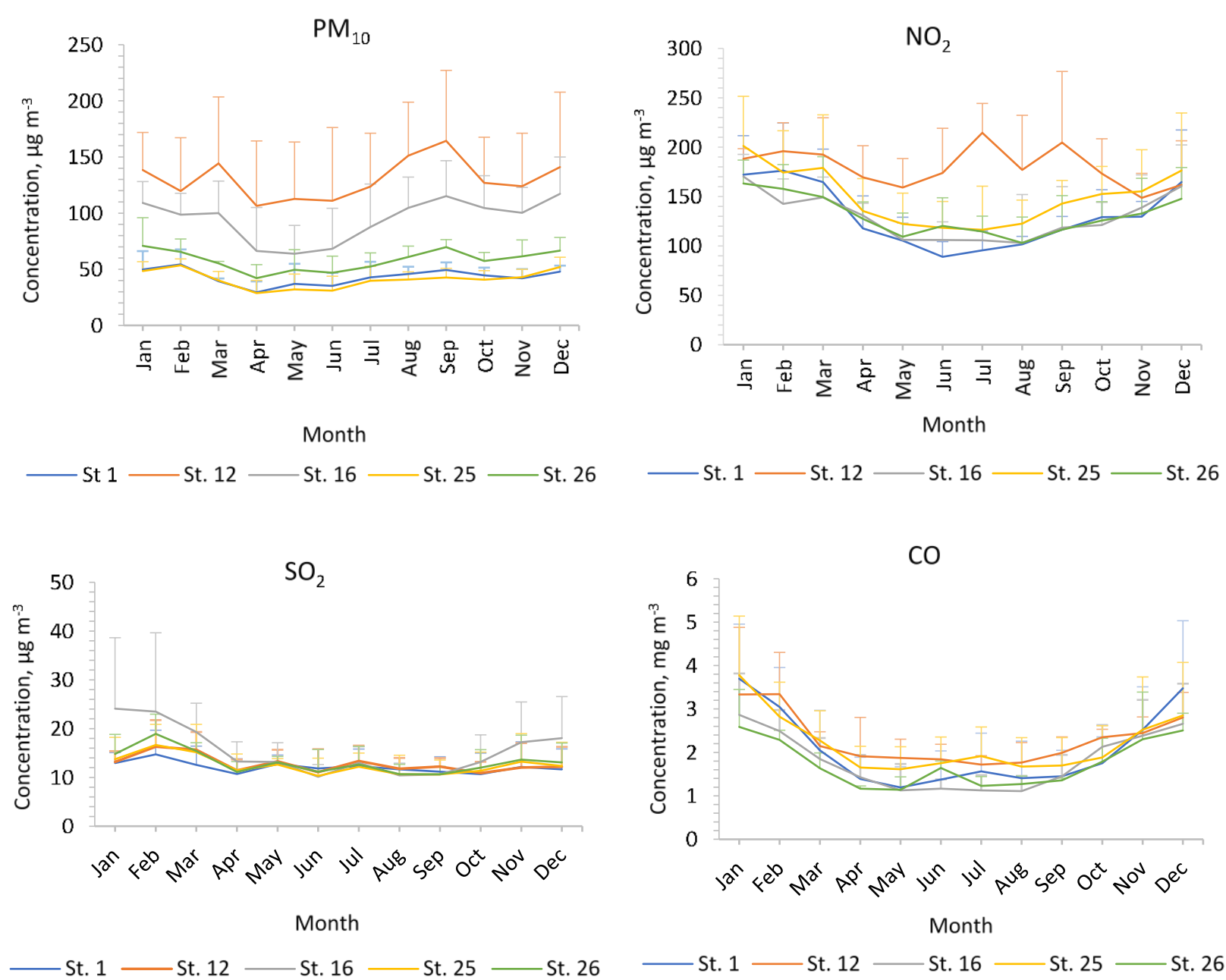

Fig. 3. Annual cycle of the $\mathrm{PM}_{10}, \mathrm{NO}_{2}, \mathrm{SO}_{2}$, and $\mathrm{CO}$ based on their monthly average concentrations for the period 20132017.

minimum monthly average of $0.3 \mathrm{~m} \mathrm{~s}^{-1}$ in January, whereas the highest value was observed in the warm season with the maximum monthly average of $0.5 \mathrm{~m} \mathrm{~s}^{-1}$ in August (Fig. 4). The relative humidity had the opposite behavior: the lowest values were observed in the warm season with the minimum monthly average in July (41.4\%) whereas the highest values were found in the cold season with the maximum monthly average $82.2 \%$ in December. Precipitation had a seasonal fluctuation with several peaks in December $(9.4 \mathrm{~mm})$, April $(7.7 \mathrm{~mm})$, and August (6 mm). From the seasonal variations, it can be concluded that pollutant concentrations have trends similar to the relative humidity, while they follow different seasonal variations with precipitation and wind speed.

\section{Spatial Differences: Districts}

The obtained results suggest that all the pollutants exceeded 24-hour mean WHO Air Quality Guideline at least once a year at all stations, and the magnitude of exceedances were different by pollutants. Spatial variations were substantial for the daily concentrations of $\mathrm{PM}_{10}$. In 2013-2017, the share of the number of days exceeding $\mathrm{PM}_{10}$ WHO daily limit value $\left(50 \mu \mathrm{g} \mathrm{m}^{-3}\right)$ was lowest in Bostandyk district $(19 \%)$, followed by Auezov (27\%) and Zhetysu (57\%) districts, and highest at Almaly district (65\%) (Fig. 5). In Almaly and Zhetysu districts, the concentrations of $\mathrm{PM}_{10}$ were higher than $100 \mu \mathrm{g} \mathrm{m}^{-3}$ (exceeding the daily limit by two times) in $48 \%$ and $33 \%$ of days of the year, respectively. The WHO daily limit was exceeded more than 3 times $\left(150 \mu \mathrm{g} \mathrm{m}^{-3}\right)$ in those districts in $25 \%$ and $10 \%$ days of the year (higher than $150 \mathrm{\mu g} \mathrm{m}^{-3}$ ), respectively.

For $\mathrm{SO}_{2}$, daily WHO limit exceedances were 8-17\% days of the year (Fig. 6). At the Zhetysu district, in 14 days, the values exceeded three times the daily $\mathrm{SO}_{2}$ limit (over 20132017). CO daily concentration levels were not exceeding the EU daily limit value of $10 \mathrm{mg} \mathrm{m}^{-3}$ in most of the days during the year, with only 1-5 days exceedance.

\section{Impact of the Elevation and Distance to the Coal-fired Power Plant}

The elevation of the city varies between $600 \mathrm{~m}$ and 1300 $\mathrm{m}$ due to the proximity to the mountains. There is an inverse correlation for $\mathrm{PM}_{10}\left(R^{2}=0.44\right)$ and $\mathrm{SO}_{2}\left(R^{2}=0.81\right)$ with the elevation of the monitoring station. At the same time, there is a very low correlation of elevation with $\mathrm{NO}_{2}\left(R^{2}=0.005\right)$ and $\mathrm{CO}\left(R^{2}=0.14\right)$ (Fig. 6). This may indicate that the $\mathrm{PM}_{10}$ and $\mathrm{SO}_{2}$ emissions were generated by coal power plants and 

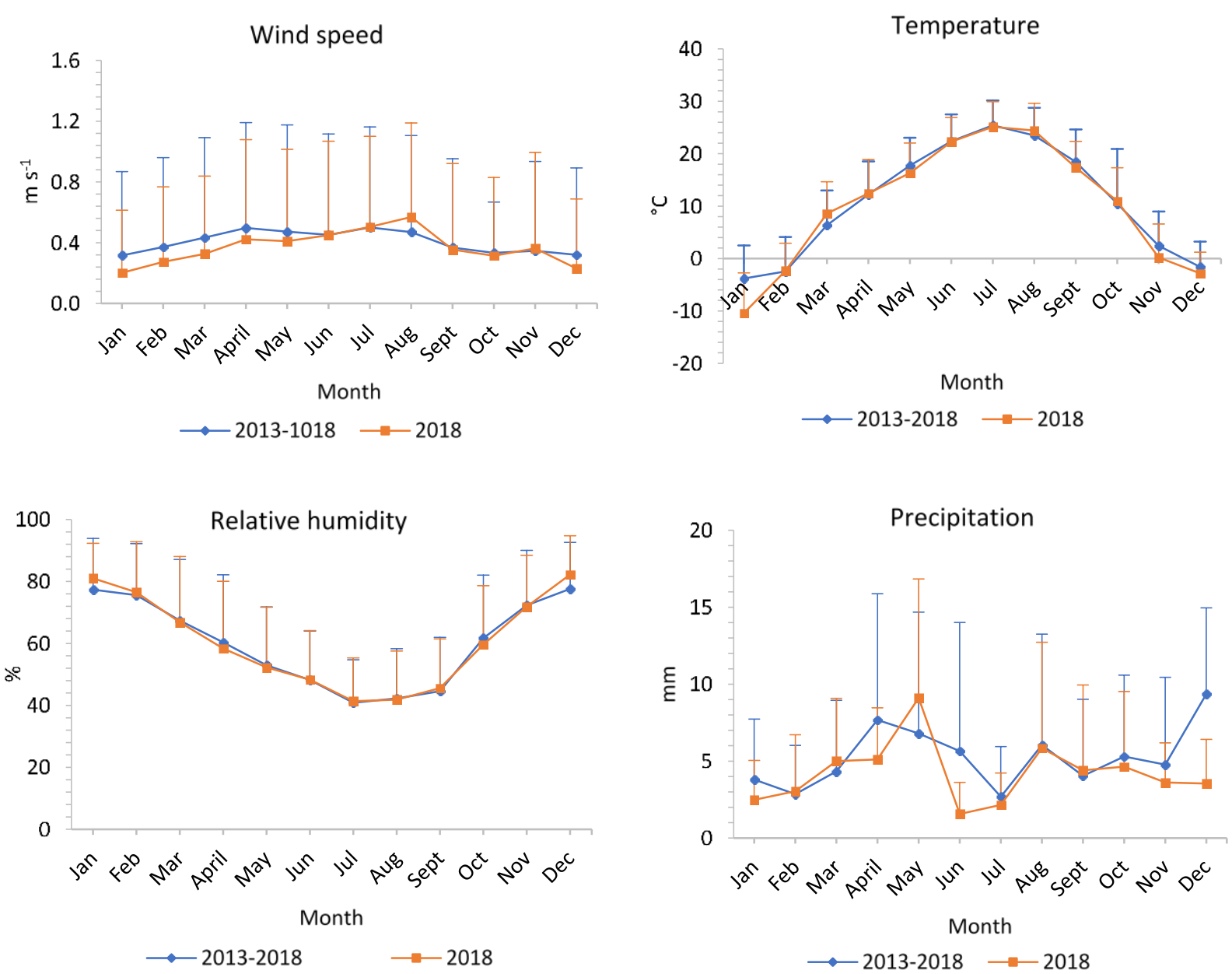

Fig. 4. Monthly average values of wind speed, temperature, relative humidity and precipitation (rp5.kz) for the period 20132018.

small-scale coal-fired heating systems located mainly in the northern areas at the low elevations, while $\mathrm{NO}_{2}$ and $\mathrm{CO}$ emissions were caused by transport vehicles which are almost evenly spread across the city. World Bank (2013) also suggested that highly elevated $\mathrm{NO}_{2}$ and $\mathrm{CO}$ concentrations in Almaty were caused by the emissions from transport.

Higher levels of air pollution with $\mathrm{PM}_{10}$ and $\mathrm{SO}_{2}$ at the lower elevations could also be impacted by the topography and meteorological conditions, e.g., mountain-valley circulations, although greatest part of the year is characterized by stable atmospheric conditions (no wind or low wind speed). Future studies should concentrate on the impact of mountain-valley wind circulation on air pollution using high spatiotemporal disaggregated data on meteorology and concentrations of pollutants.

Largest coal-fired combined heat and power plant in the city is CHP-2 (located at the north-west), with an installed electrical capacity of $510 \mathrm{MW}$ and thermal capacity of $1176 \mathrm{Gcal} \mathrm{h}^{-1}$ (ALES, 2019). CHP-2 has increased its power generation from 2.63 billion $\mathrm{kWh}$ to 2.68 billion $\mathrm{kWh}$ and heat generation from 3.2 million Gcal to 3.4 million Gcal over 2016-2018 (ALES, 2019). These increasing levels of electricity and heat generation may also imply increasing levels of coal combustion at this power plant. Values of coal combustion by years/months are not available for CHP-2. It is reported that CHP-2 has fly-ash separator (ALES, 2019), but efficiency of cleaning for each pollutant $\left(\mathrm{PM}_{2.5}, \mathrm{PM}_{10}\right.$, $\mathrm{NO}_{2}, \mathrm{SO}_{2}$ ) is not reported publicly. Different opinions exist on the impact of the CHP-2 on the air quality degradation of the city. Officials (municipality of Almaty City) claim that "the main source of air pollution is motor vehicles" as total emissions of the transport sector accounted for 79,486 tons in 2016, which represent "sum of all pollutant emissions", without accounting for health risk of each pollutant (Municipality of Almaty City, 2018). Municipality of Almaty City (2018) reported estimated total emissions from stationary sources at 38,800 tons, the majority ( $81 \%$ ) of which (31587 tons) is generated from coal-fired power plant CHP-2 (Municipality of Almaty City, 2018). On the other hand, Airkaz claims as "transport is not the main source of emissions" based on the peak values of $\mathrm{PM}_{2.5}$ were detected during the winter periods (Informburo, 2019). From another official report prepared by Ecoservice (2017), where inventory of emissions for Almaty is presented, it can be concluded that $91 \%$ of the estimated transport emissions is contributed by $\mathrm{CO}$, which is much less toxic (for the same mass) than other pollutants $\left(\mathrm{PM}_{2.5}, \mathrm{NO}_{2}, \mathrm{SO}_{2}\right)$ and its inclusion in total emissions results in the distorted estimation of the input of different sources. 

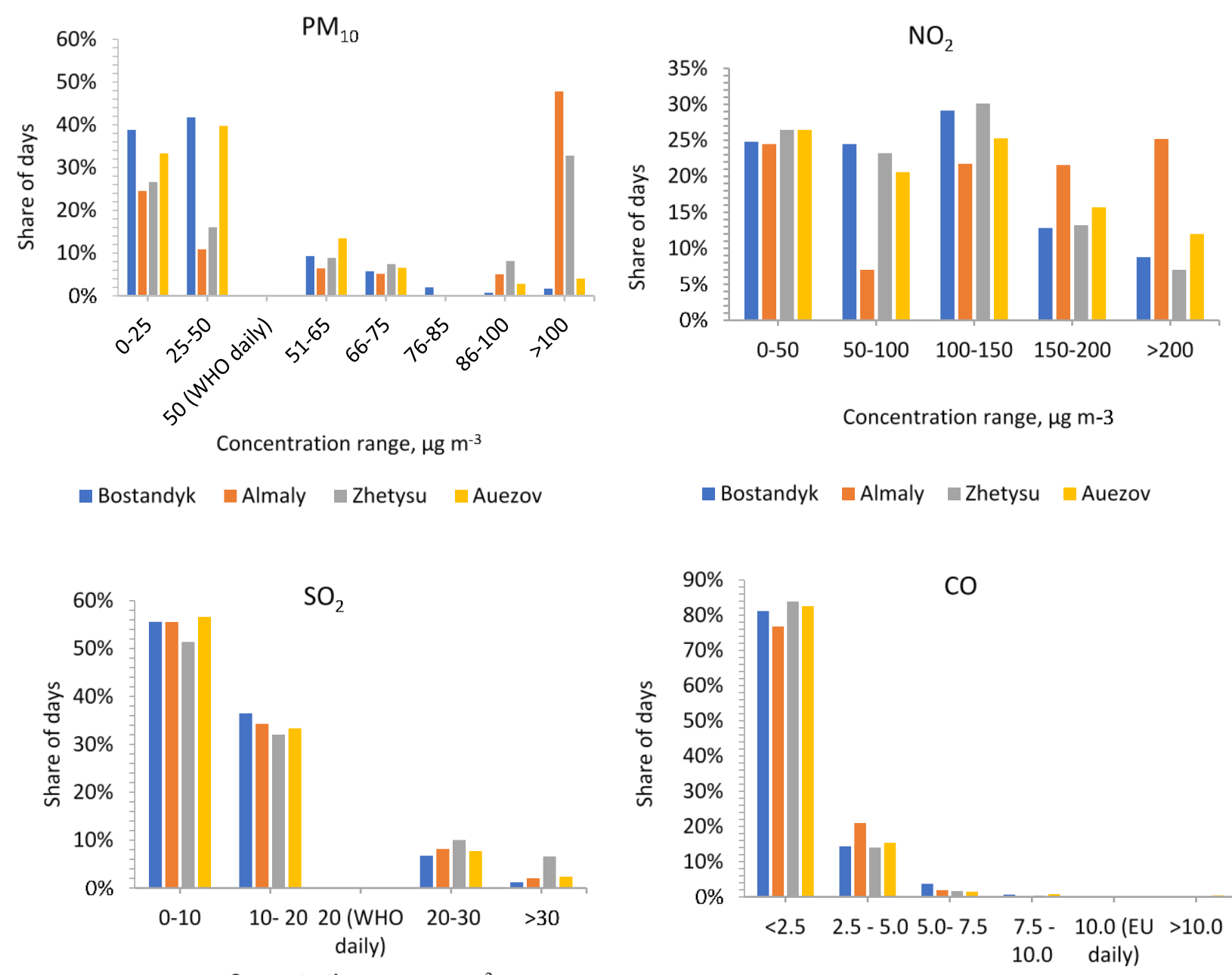

Concentration range, $\mu \mathrm{g} \mathrm{m}^{-3}$

Bostandyk Almaly Zhetysu Auezov

$$
\begin{gathered}
\text { Concentration range, } \mathrm{mg} \mathrm{m}^{-3} \\
\square \text { Bostandyk } \square \text { Almaly } \square \text { Zhetysu } \square \text { Auezov }
\end{gathered}
$$

Fig. 5. Share of days in different ranges of daily average concentrations of $\mathrm{PM}_{10}, \mathrm{SO}_{2}, \mathrm{NO}_{2}$, and $\mathrm{CO}$ by districts of Almaty in 2013-2017 years.

If $\mathrm{CO}$ is excluded from the total sum, share of sources from the total emissions ( $\mathrm{PM}, \mathrm{NO}_{2}, \mathrm{SO}_{2}$ ) becomes $17 \%$ transport, $75 \%$ stationary combustion and $8 \%$ domestic heating. For more accurate estimation of the input of different sources into a concentration of each pollutant, a more accurate source apportionment study with receptor modeling or inventory of emissions is required. Estimating the sources contribution from the sum of emissions of different pollutants is not methodologically correct due to different levels of risks of pollutants for the given mass.

Monitoring stations of NAQMN are located at a varying distance to CHP-2, from 7 to $13 \mathrm{~km}$. Annual average concentrations of $\mathrm{NO}_{2}, \mathrm{SO}_{2}, \mathrm{CO}$ and $\mathrm{PM}_{10}$ had low correlation coefficients $\left(R^{2}=0.01-0.14\right)$ with the distance to CHP-2. None of the stations are located close to CHP-2, and this could explain the low correlation values.

\section{Impact of Wind Direction and Speed}

In the majority of the studied periods, the "no wind conditions" were $62 \%$ in July and $71 \%$ (the highest) in
December. Thus, wind speed conditions are generally unfavorable for pollution dispersion. Prevailing wind direction is North and North-East, which reaches its maximum share of $6.6-11 \%$ in cold months and of $5.4-7.9 \%$ in the summer months. Remaining wind directions (blowing from the east, south-east, south, southwest, west, and north-west) had an opposite trend of increasing share in the warmer periods and decreasing in colder months. The least prevailing wind direction was north-west direction with $0.3-2.5 \%$.

Results demonstrate that there is no dominant prevailing wind direction at which the average pollutant concentration was highest or lowest for all seasons and all pollutants. Maximum average concentrations of $\mathrm{PM}_{10}$ and $\mathrm{SO}_{2}$ in winter months were observed when the wind was blowing from the north-west direction. This may address the contribution of the coal-fired CHP-2 located in the northwest zone of the city. The average concentration of $\mathrm{NO}_{2}$ in the winter period was the highest when there was no wind. This may indicate that the other sources (e.g., transport) can have a higher contribution to $\mathrm{NO}_{2}$ levels in the city in the 

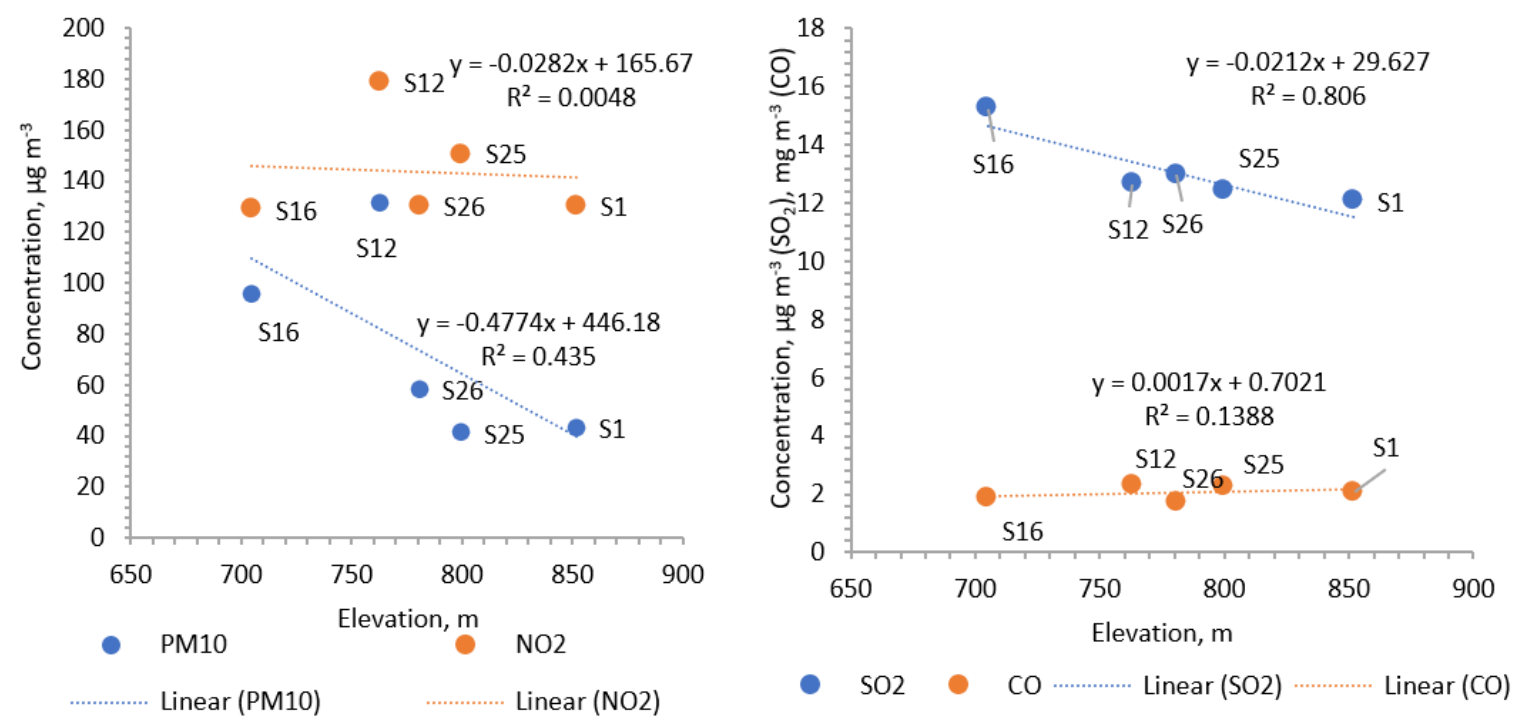

Fig. 6. Effect of the elevation of the monitoring station (x-axis) on the annual average concentrations of $\mathrm{PM}_{10}, \mathrm{NO}_{2}, \mathrm{SO}_{2}$, and $\mathrm{CO}$ over 2013-2017 years in $\mu \mathrm{g} \mathrm{m}^{-3}$ (except for $\mathrm{CO}$, which is reported in $\mathrm{mg} \mathrm{m}^{-3}$ ) (y-axis).

wintertime. During the summertime, maximum average concentrations of $\mathrm{PM}_{10}, \mathrm{SO}_{2}$, and $\mathrm{NO}_{2}$ were observed with north-eastern, north-western and northern winds, respectively. This can indicate that $\mathrm{SO}_{2}$ concentration was affected by the coal-fired CHP plants (located in the northwest), while $\mathrm{PM}_{10}$ and $\mathrm{NO}_{2}$ concentrations were affected by other sources (transport) during the summertime.

\section{Analysis of the Airkaz Data}

Annual average $\mathrm{PM}_{2.5}$ concentration was $53 \mu \mathrm{g} \mathrm{m}^{-3}$ in 2018, exceeding the WHO annual $\mathrm{PM}_{2.5}$ limit 5.3 times, with substantial spatial differences from 27 to $81 \mu \mathrm{g} \mathrm{m}^{-3}$. This is substantially higher than the population-weighted average in 2015 in Canada and USA $\left(7.9 \mu \mathrm{g} \mathrm{m}^{-3}\right)$, Western Europe $\left(13.4 \mu \mathrm{g} \mathrm{m}^{-3}\right)$, global average $\left(43.7 \mu \mathrm{g} \mathrm{m}^{-3}\right)$, while it is lower than weighted average in China $\left(57.5 \mu \mathrm{g} \mathrm{m}^{-3}\right)$ and India (74 $\mathrm{\mu g} \mathrm{m}^{-3}$ ) (Burnett et al., 2018).

The second data set (Airkaz) indicates severe air pollution levels with $\mathrm{PM}_{2.5}$. Annual average and daily average $\mathrm{PM}_{2.5}$ concentrations exceeded WHO limit values at all stations. Annual average concentrations by stations exceeded the WHO annual limit by 2.7-8.1 times, while daily average concentrations exceeded the daily WHO limit values in the $42-87 \%$ of the days of the year. These levels are higher than the exceedances of $\mathrm{PM}_{10}$ provided by NAQMN. This indicated that the magnitude of the exceedance of daily and annual limits was higher with the Airkaz network $\mathrm{PM}_{2.5}$ data compared to NAQMN $\mathrm{PM}_{10}$ data, although the levels of $\mathrm{PM}_{2.5}$ from Airkaz cannot be directly compared with NAQMN $\mathrm{PM}_{10}$ data (estimated from TSP) because the stations are located at different locations and the periods of measurements are different (2018 for Airkaz and 2013-2017 for NAQM).

\section{Spatial Differences: Districts}

Fig. 7 illustrates the estimated share of time in the year in which $\mathrm{PM}_{2.5}$ exceeds WHO daily limit value in Almaty.

Majority of the year, the WHO daily limit value was exceeded: $87 \%$ in Turksib district, $67 \%$ in Alatau district, $61 \%$ in Almaly district, 59\% in Auezov district and 56\% in Bostandyk district, with the exception of Medeu district with slightly lower than a half year (43\%). Thus, the Airkaz depicts considerably higher $\mathrm{PM}_{2.5}$ exceedance levels in southern areas of the city (43-59\%) compared to NAQMN $\mathrm{PM}_{10}$ exceedance levels (19-27\%). Share of the days with the daily concentrations higher than $75 \mu \mathrm{g} \mathrm{m}^{-3}$ was highest at Turksib district (35\%) followed by Alatau (31\%), Almaly (25\%), Auezov (25\%), Bostandyk (21\%), and Medeu (9\%) districts.

At 21 days of 2018, average daily $\mathrm{PM}_{2.5}$ concentration exceeded $250 \mu \mathrm{g} \mathrm{m}^{-3}$ at least in one station. Concentrations above $250 \mu \mathrm{g} \mathrm{m}^{-3}$ correspond to "Hazardous" level of US EPA AQI level indicating severe health impacts on all groups of population with an "emergency" situation (EPA, 2016). In Almaty, such an "emergency" situation due to air pollution has never been announced, probably because the methodology for estimation and the procedure for the announcement by officials is not straightforward, but complicated and bureaucratic.

\section{Analysis of the Elevation and Distance to the Coal-fired Power Plant}

Similar to NAQMN $\mathrm{PM}_{10}$ data, there was a significant inverse correlation of $\mathrm{PM}_{2.5}$ concentration $\left(R^{2}=0.64\right)$ with elevation (Fig. 8). Thus, the air quality improved with the increase of elevation and the air quality limit values were also exceeded even at the highest locations, although to the lower extent (2.7 times). $\mathrm{PM}_{2.5}$ stations were located at varying distances to the CHP-2 from the closest $4 \mathrm{~km}$ to the farthest $18 \mathrm{~km}$. The average annual concentration negatively correlated with the distance to the CHP-2 $\left(R^{2}=0.51\right)$ indicating that $\mathrm{PM}_{2.5}$ concentration increases with the declining distance to the CHP-2. There was a better correlation with the Airkaz data compared to the NAQMN data, possibly because Airkaz stations located closer $(4 \mathrm{~km})$ than NAQMN 


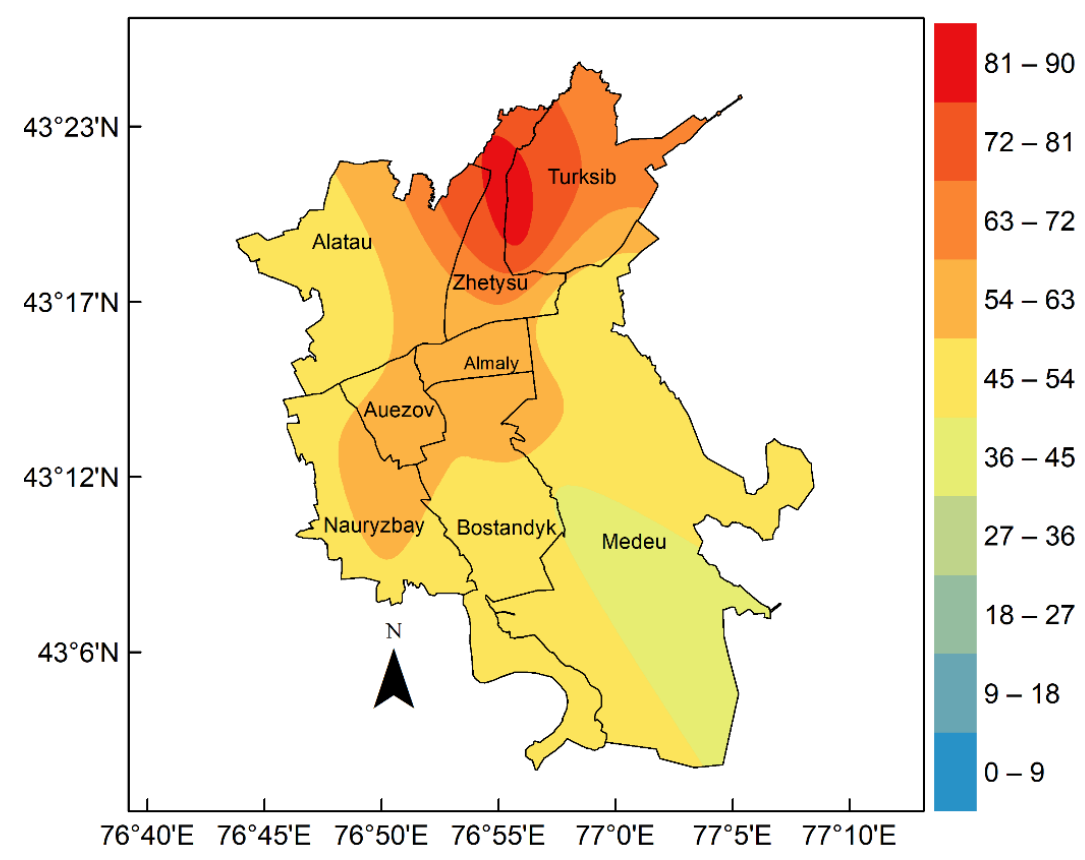

Fig. 7. Estimated share of days in the year, in which $\mathrm{PM}_{2.5}$ exceeded WHO daily limit value.
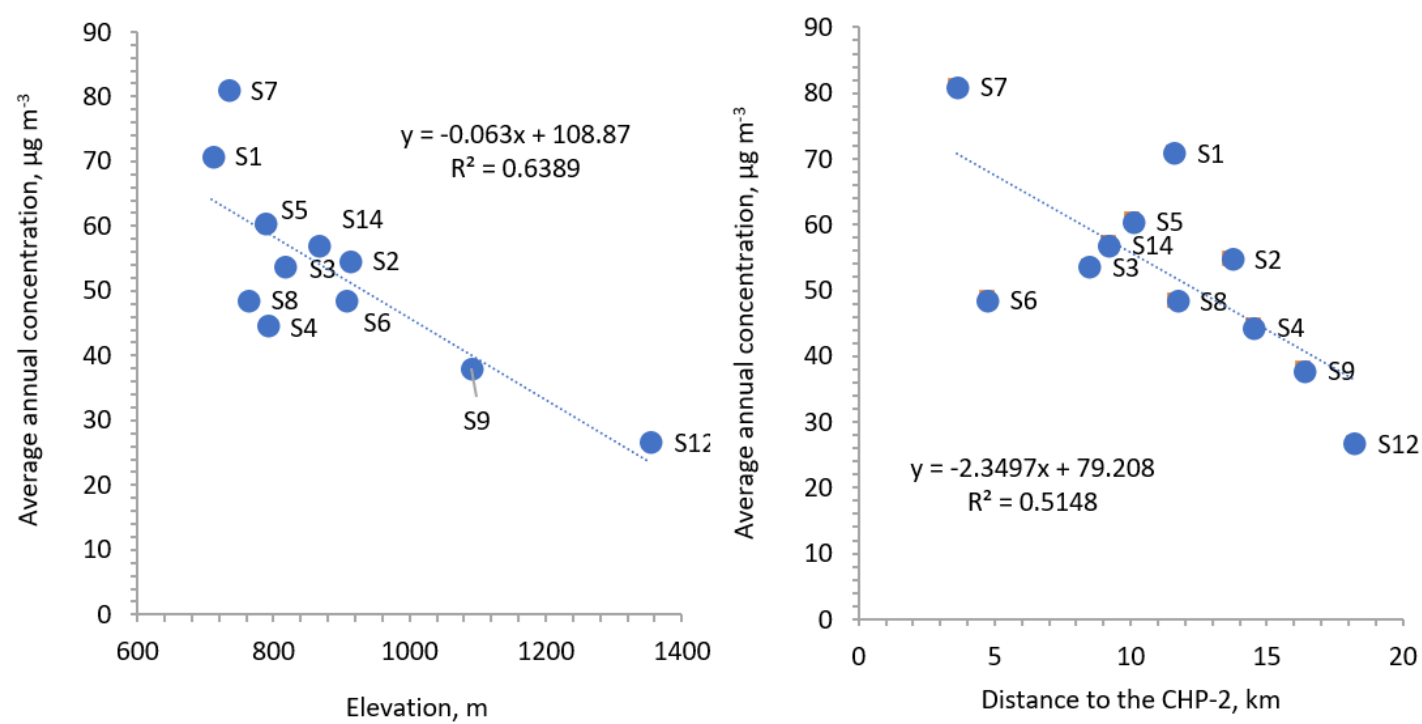

Fig. 8. Average annual concentration of $\mathrm{PM}_{2.5}$ in 2018 and elevation (left); average annual concentration and the distance to the CHP-2 (right).

station $(7 \mathrm{~km})$. Another reason could be that CHP-2 has a higher removal efficiency for coarse particles $\left(\mathrm{PM}_{10}\right)$ than for fine particles $\left(\mathrm{PM}_{2.5}\right)$. The results indicate the urgent need for measures to reduce emissions from CHP-2: a fuel switching to gas, installing advanced emissions control technologies, and/or constructing new clean power and heat facilities (gas, renewable sources).

\section{Monthly Variations}

Wintertime peak was also pronounced with Airkaz data as maximum to minimum monthly share was 13.7 (Fig. 9). Maximum monthly concentrations were observed in January at ten stations and in December at one station. January and
December were characterized by the lowest average monthly temperatures of $-10^{\circ} \mathrm{C}$ and $-3^{\circ} \mathrm{C}$, respectively, lowest average monthly wind speed $\left(0.2 \mathrm{~m} \mathrm{~s}^{-1}\right)$ and the highest humidity (81-82\%). In Almaty, minimum monthly concentrations at all stations were observed in the warm months: May (3 stations), June (3 stations), July (3 stations), August (2 stations). These results are similar to the monthly variations of NAQMN data for other pollutants.

In Tehran, the stability of the atmosphere was examined using the data from the atmospheric radiosondes data at a synoptic station (Alizadeh-Choobari et al., 2016). Tehran is surrounded by high mountains on two sides; frequent temperature inversions in winter limit horizontal dispersion 


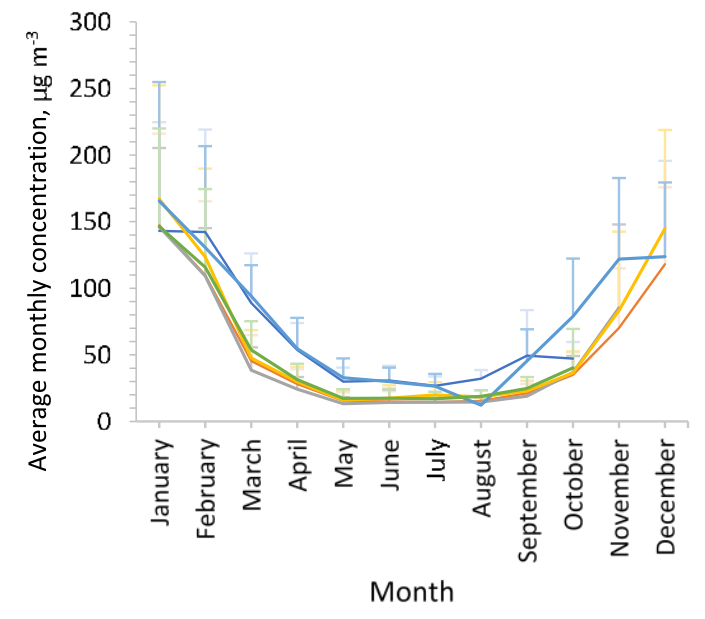

$\longrightarrow$ St. $1 \longrightarrow$ St. $3 \longrightarrow$ St. $4 \longrightarrow$ St.5 St.7 St. 8

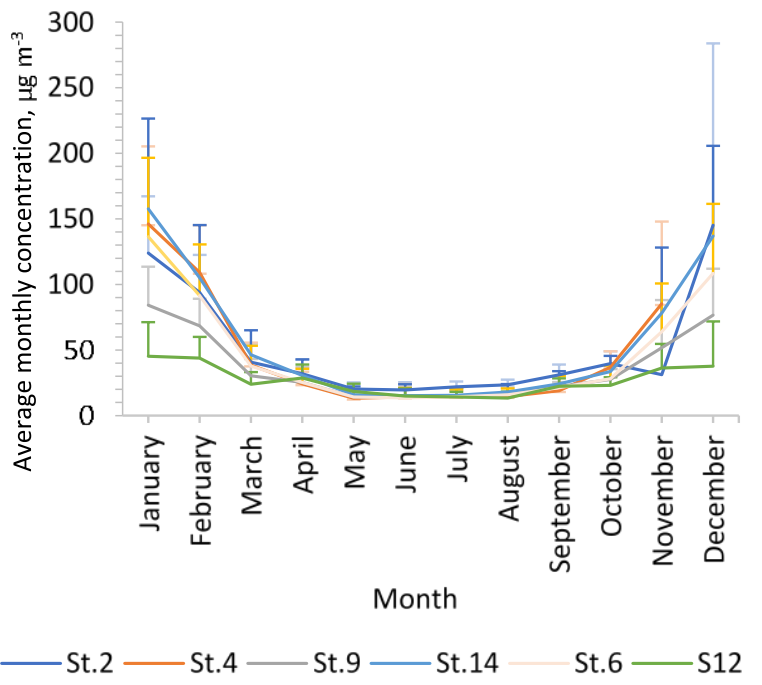

Fig. 9. Monthly average concentrations of $\mathrm{PM}_{2.5}$ and standard deviations by stations.

of the pollutants and thus contribute to the high levels of pollution (Alizadeh-Choobari et al., 2016). Ulaanbaatar (capital of Mongolia) is also located in a basin surrounded by mountains and is characterized by long and cold winters. Using lidar and ground-level meteorological observations, Wang et al. (2017) studied the variation of the atmospheric boundary layer (ABL) during the 2010 heating season in the episodic days with high air pollution. Wang et al. (2017) demonstrated that the atmospheric boundary layer decreased in winter and dropped below $800 \mathrm{~m}$ after the second cold wave, which contributed to a high concentration of $\mathrm{PM}_{2.5}$ in Ulaanbaatar. In Almaty, there is a lack of meteorological observations on the atmospheric boundary layer. Contribution of surface inversion layer on winter episodes could also be significant for Almaty, and future studies are needed to confirm this statement quantitatively.

\section{Correlation with Meteorological Factors}

Daily average concentrations of $\mathrm{PM}_{2.5}$ were generally weakly correlated with the temperature, with $R^{2}$ varying from 0.09 to 0.37 (Table 3). The determination coefficient was lower at the most polluted districts (Alatau and Turksib districts) and higher at the cleaner districts (Medeu district, $\left.R^{2}=0.365\right)$. The daily average concentrations of $\mathrm{PM}_{2.5}$ did not correlate with the wind speed and precipitation $\left(R^{2}\right.$ close to zero). This may be attributed to the fact that wind speed was lower than $0.5 \mathrm{~m} \mathrm{~s}^{-1}$ in 234 days in 2018, and there was no precipitation in 218 days.

At all the stations, the majority of the episode days (the top $25^{\text {th }}$ percentile) were characterized with no precipitation (58-68\% from total episode days); with wind speed less or equal to $0.5 \mathrm{~m} \mathrm{~s}^{-1}$ (excluding 0) with the share of $68-74 \%$ from total episode days.

\section{CONCLUSIONS}

There is a severe air quality degradation in Almaty, which is confirmed by both national air quality monitoring network (NAQMN) and Airkaz independent monitoring network.
There was an overall increasing trend of annual $\mathrm{PM}_{10}$ concentration in the city over the period 2013-2017. $\mathrm{NO}_{2}$ and $\mathrm{SO}_{2}$ concentration levels had fluctuating trends, and $\mathrm{CO}$ had a declining trend. This may indicate changing the structure of sources of emissions, with a declining contribution of transport sources due to the improvement of the public transport system and increasing contribution of coal combustion due to the increased heat and electricity generation.

Winter peaks demonstrate the high contribution of largeand small-scale coal combustion for heating because traffic emissions are likely to be stable throughout the year. Pollution levels in the wintertime could also be exacerbated with the lower level of the atmospheric boundary layer and lower wind speed. The annual average $\mathrm{PM}_{2.5}$ concentration negatively correlated with the distance to the CHP-2. Coal-fired combined heat and power plants could be significant contributors to $\mathrm{PM}$ and $\mathrm{SO}_{2}$ pollution in the city, although further research such as dispersion modeling and source-apportionment studies are needed to quantify its impact. There is an inverse correlation with the elevation for $\mathrm{SO}_{2}, \mathrm{PM}_{2.5}, \mathrm{PM}_{10}$, while no correlation was observed for $\mathrm{NO}_{2}$ and CO. $\mathrm{SO}_{2}, \mathrm{PM}_{2.5}, \mathrm{PM}_{10}$, which could be mainly generated by point sources typically located at lower elevations (e.g. power plants, residential heating), while $\mathrm{NO}_{2}$ and $\mathrm{CO}$ could originate from nonpoint sources distributed evenly across the city (e.g., transport). Topographic and meteorological conditions may contribute to the higher levels of pollutants at the lower elevation.

The majority of the days during the year in the city is characterized by stable atmospheric conditions, and, therefore, the correlation of pollutant concentrations with meteorological parameters was low. In this study, the height of the atmospheric boundary layer was not analyzed. Future studies are needed to investigate the relationship between the height of the atmospheric boundary layer and the concentrations of pollutants to explore the spatial differences in the meteorological parameters which can be caused by the differences in elevation and urban structures. The monitoring of other pollutants such as ozone and polycyclic aromatic hydrocarbons has to be conducted in Almaty. 
Table 3. Determination coefficients $\left(R^{2}\right)$ between daily average concentrations of $\mathrm{PM}_{2.5}$ and meteorological factors (temperature, precipitation, wind speed)

\begin{tabular}{llll}
\hline & Temperature & Wind speed & Precipitation \\
\hline Turksib district & & & \\
$\quad$ S1 & 0.147 & 0.041 & 0.005 \\
Alatau district & & & 0.006 \\
$\quad$ S7 & 0.090 & 0.017 & 0.002 \\
S8 & 0.197 & 0.034 & 0.001 \\
Bostandyk district & & & 0.004 \\
$\quad$ S2 & 0.149 & 0.028 & 0.003 \\
S3 & 0.187 & 0.031 & 0.023 \\
S6 & 0.207 & 0.030 & 0.024 \\
S9 & 0.291 & 0.025 & 0.003 \\
Medeu district & 0.365 & 0.057 & 0.008 \\
$\quad$ S4 & & & \\
Auezov district & 0.209 & 0.028 & \\
$\quad$ S14 & & 0.029 & \\
Almaly district & 0.179 & & \\
S5 & & & \\
\hline
\end{tabular}

Urgent measures are needed to reduce emissions from CHP-2: switching it to gas, installing advanced emissions control technologies, or constructing new clean power and heat plant (e.g., gas, renewable energy sources). Household coal combustion should be discouraged, with incentives provided to switch to cleaner options. Measures in the transport sector could include stringent standards for vehicle emissions and further improvement of the public transport system (e.g., expansion of the subway routes). In households, a gradual coal ban can be introduced.

\section{ACKNOWLEDGMENT}

This work was supported by the Postdoctoral Fellowship Program of Al-Farabi Kazakh National University. We are grateful to the Kazhydromet and Airkaz for providing the data on pollutant concentrations.

\section{REFERENCES}

ALES (2019). Almaty power plants. http://www.ales.kz/ru/ company-activities

Alizadeh-Choobari, O., Bidokhti, A.A., Ghafarian, P. and Najafi, M.S. (2016). Temporal and spatial variations of particulate matter and gaseous pollutants in the urban area of Tehran. Atmos. Environ. 141: 443-453. https://doi.org /10.1016/j.atmosenv.2016.07.003

Baimatova, N., Kenessov, B., Koziel, J.A., Carlsen, L., Bektassov, M. and Demyanenko O.P. (2016). Simple and accurate quantification of BTEX in ambient air by SPME and GC-MS. Talanta 154: 46-52. https://doi.org/10.1016 /j.talanta.2016.03.050

Burnett, R., Chen, H., Szyszkowicz, M., Fann, N., Hubbell, B., Pope, C.A., Apte, J.S., Brauer, M., Cohen, A., Weichenthal, S., Coggins, J., Di, Q., Brunekreef, B., Frostad, J., Lim, S.S., Kan, H., Walker, K.D., Thurston, G.D., Hayes, R.B., Lim, C.C., Turner, M.C., Jerrett, M., Krewski, D., Gapstur, S.M., Diver, W.R., Ostro, B., Goldberg, D., Crouse, D.L.,
Martin, R.V., Peters, P., Pinault, L., Tjepkema, M., van Donkelaar, A., Villeneuve, P.J., Miller, A.B., Yin, P., Zhou, M., Wang, L., Janssen, N.A.H., Marra, M., Atkinson, R.W., Tsang, H., Quoc Thach, T., Cannon, J.B., Allen, R.T., Hart, J.E., Laden, F., Cesaroni, G., Forastiere, F., Weinmayr, G., Jaensch, A., Nagel, G., Concin, H. and Spadaro, J.V. (2018). Global estimates of mortality associated with longterm exposure to outdoor fine particulate matter. Proc. Natl. Acad. Sci. U.S.A. 115: 9592-9597. https://doi.org/ 10.1073/pnas. 1803222115

Carlsen, L., Kenessov, B.N., Baimatova, N.Kh. and Kenessova, O. (2013). Assessment of the air quality of Almaty. Focussing on the traffic component. Int. J. Biol. Chem. 5: 49-69. https://doi.org/10.1016/j.talanta.2016.0 3.050 .

Cohen, A.J., Brauer, M., Burnett, R., Anderson, H.R., Frostad, J., Estep, K., Balakrishnan, K., Brunekreef, B., Dandona, L., Dandona, R., Feigin, V., Freedman, G., Hubbell, B., Jobling, A., Kan, H., Knibbs, L., Liu, Y., Martin, R., Morawska, L., Pope, C.A., III, Shin, H., Straif, K., Shaddick, G., Thomas, M., van Dingenen, R., van Donkelaar, A., Vos, T., Murray, C.J.L. and Forouzanfar, M.H. (2017). Estimates and 25-year trends of the global burden of disease attributable to ambient air pollution: An analysis of data from the Global Burden of Diseases Study 2015. Lancet 389: 1907-1918. https://doi.org/10.1016/S0 140-6736(17)30505-6

Committee of Statistics of the Ministry of national economy of the Republic of Kazakhstan (2019a). Population of the Republic of Kazakhstan by sex and individual age groups at the beginning of the year. http://stat.gov.kz/getImg?id= ESTAT259817

Committee of Statistics of the Ministry of national economy of the Republic of Kazakhstan (2019b). Passenger car transport http://old.stat.gov.kz/getImg?id=ESTAT099960

Concept on the transition of the Republic of Kazakhstan to the "green economy" (2013). https://greenkaz.org/images/ for_news/pdf/npa/koncepciya-po-perehodu.pdf 
Darynova, Z., Maksot, A., Kulmukanova, L., Malekipirbazari, M., Sharifi, H., Torkmahalleh, M.A. and Holloway, T. (2018). Evaluation of $\mathrm{NO}_{2}$ column variations over the atmosphere of Kazakhstan using satellite data. J. Appl. Remote Sens. 12: 042610. https://doi.org/10.1117/1.JRS. 12.042610

Ecoservice (2017). Setting environmental targets for the city of Almaty. https://ecoservice.kz/news/target-values-p1/

EPA (2016). Revised air quality standards for particle pollution and updates to the air quality index. https://www.epa.gov/sites/production/files/2016-04/docu ments/2012_aqi_factsheet.pdf

European Envionment Agency (2019). Air quality in Europe - 2018 report. https://www.eea.europa.eu/publications/ai r-quality-in-europe-2018/download

Informburo (2019). Conversation with an eco-activist who proved that the main problem of air pollution in Almaty. https://informburo.kz/interview/razgovor-s-ekoaktivistomdokazavshim-chto-glavnaya-problema-zagryazneniya-vo zduha-v-almaty-ne-transport.html

Issanova, G. and Abuduwaili, J. (2017). Erratum to: Aeolian Processes as Dust Storms in the Deserts of Central Asia and Kazakhstan, In Aeolian Process as Dust Storms in the Deserts of Central Asia and Kazakhstan, Springer Singapore, Singapore, pp. E1-E1.

Kazenergy (2017). The national energy report 2017. http://www.kazenergy.com/upload/document/energy-rep ort/National_Energy_Report-ENGLISH_03.09.pdf

Kenessariyev, U., Golub, A., Brody, M., Dosmukhametov, A., Amrin, M., Erzhanova, A. and Kenessary, D. (2013). Human health cost of air pollution in Kazakhstan. $J$. Environ. Prot. 4: 869-876. https://doi.org/10.4236/jep.2 013.48101

Kerimray, A., De Miglio, R., Rojas-Solórzano, L. and Ó Gallachóir, B.P. (2018). Causes of energy poverty in a cold and resource-rich country: Evidence from Kazakhstan. Local Environ. 23: 178-197. https://doi.org/ 10.1080/13549839.2017.1397613

Kerimray, A., Kenessov, B. and Karaca, F. (2019). Trends and health impacts of major urban air pollutants in Kazakhstan. J. Air Waste Manage. Assoc. 69: 1331-1347. https://doi.org/10.1080/10962247.2019.1668873 (Retraction published 24 Apr 2020, J. Air Waste Manage. Assoc. 70: 657) (Later accepted in J. Air Waste Manage. Assoc. https://doi.org/10.1080/10962247.2020.1813837)

Municipality of Almaty City (2018). Development Program "Almaty 2020". https://almaty.gov.kz/page.php?page_id $=3239$ \&lang $=1$

Nazhmetdinova, A., Sarmanbetova, G. and Alena, M. (2018). The characteristics of pollution in the big industrial cities of Kazakhstan by the example of Almaty. J. Environ. Health Sci. Eng. 16: 81-88. https://doi.org/10.1007/s402 01-018-0299-1

Nugmanova, D., Feshchenko, Y., Iashyna, L., Gyrina, O., Malynovska, K., Mammadbayov, E., Akhundova, I., Nurkina, N., Tariq, L., Makarova, J. and Vasylyev, A. (2018b). The prevalence, burden and risk factors associated with chronic obstructive pulmonary disease in Commonwealth of Independent States (Ukraine, Kazakhstan and Azerbaijan): Results of the CORE study. BMC Pulm. Med. 18: 26. https://doi.org/10.1186/s12890-018-0589-5

Nugmanova, D., Sokolova, L., Feshchenko, Y., Iashyna, L, Gyrina, O., Malynovska, K., Mustafayev, I., Aliyeva, G., Makarova, J., Vasylyev, A. and Tariq, L. (2018a). The prevalence, burden and risk factors associated with bronchial asthma in commonwealth of independent states countries (Ukraine, Kazakhstan and Azerbaijan): Results of the CORE study. BMC Pulm. Med. 18: 110. https://doi.org/10.1186/s12890-018-0676-7

Rupakheti, D., Kang, S., Bilal, M., Gong, J., Xia, X. and Cong, Z. (2019). Aerosol optical depth climatology over Central Asian countries based on Aqua-MODIS Collection 6.1 data: Aerosol variations and sources. Atmos. Environ. 207: 205-214. https://doi.org/10.1016/j.atmosenv.2019.0 3.020

Russell, A., Ghalaieny, M., Gazdiyeva, B., Zhumabayeva, S., Kurmanbayeva, A., Akhmetov, K., Mukanov, Y., McCann, M., Ali, M., Tucker, A., Vitolo, C. and Althonayan, A. (2018). A spatial survey of environmental indicators for Kazakhstan: An examination of current conditions and future needs. J. Environ. Res. 12: 735748. https://doi.org/10.1007/s41742-018-0134-7

UNDP (2017). Sustainable transport of Almaty. https://alatr ansit.kz/sites/default/files/finalnyy_otchet.pdf

United Nations Environment Program (2019). Air Pollution in Asia and the Pacific: Science-based solutions. https://ccacoalition.org/en/resources/air-pollution-asia-andpacific-science-based-solutions-summary-full-report

USGS (2019). Earth explorer. https://earthexplorer.usgs.gov/

Wang, M., Kai, K., Jin, Y., Sugimoto, N. and Dashdondog, B. (2017). Air particulate pollution in Ulaanbaatar, Mongolia: Variation in atmospheric conditions from autumn to winter. SOLA 13: 90-95. https://doi.org/10.2151/sola.2 017-017

Weather Schedule (2020). Weather in 243 countries. http://rp5.kz/

WHO (2018). WHO global ambient air quality database (update 2018). https://www.who.int/airpollution/data/citi es/en/

World Bank (2013). Towards Cleaner Industry and Improved Air Quality Monitoring in Kazakhstan. http://documents. worldbank.org/curated/en/132151468047791898/Towar ds-cleaner-industry-and-improved-air-quality-monitoringin-Kazakhstan

World Bank (2017). Municipal Energy Efficiency Plan for the City of Almaty. http://documents.worldbank.org/curated/ en/855641510934183633/pdf/121463-ESM-P130013-PU BLIC-KEEPAlmatyEEPlanNovengfinal.pdf

Received for review, September 18, 2019 Revised, February 4, 2020 Accepted, February 10, 2020 